\title{
Recollection
}

\section{Shijun Ma: keeping on exploring new areas to meet the challenge of human and social demands}

\author{
Le Kang, Ming Li \\ Beijing Institutes of Life Science, Chinese Academy of Sciences, Beijing 100101, China
}

Professor Shijun Ma (1915-1991) is a renowned Chinese ecologist. Shijun, literally in Chinese, means the finest horse, which also perfectly describes his academic life- -50 years of non-stop traveling and exploring new areas, from insects to human being, from experimental science to systematic science, from ecology to environmental science, and from nature to society.

After getting his BS degree from the Department of Biology at the Peking University in 1937, followed by working on the pest control of tobacco field for a few years, Shijun Ma went to study in the United States. He first studied insect ecology at the Utah State University (where he got his MS degree) and then at the University of Minnesota (where he was awarded Ph.D. degree), doing research on the control of the maizesnout moth's larva. In 1951, Shijun Ma spent over a month traveling in Holland, Belgium, Austria, France and Britain, attending academic conferences and meeting with famous ecologists and entomologists such as Dr. Charles Elton and Dr. Boris P. Uvarov.

In 1952, Shijun Ma finished his long travel and returned to China. He joined the Institute of Entomology (which later became a major part of the Institute of Zoology, Chinese Academy of Sciences, Beijing), Academia Sinica and established the first insect ecology laboratory in China. His first major project was to control the migratory locust plague in China. This notorious pest worldwide was also a severe problem for a country heavily relying on agricultural economy. Before deciding on the locust-controlling strategy, he spent a great amount of time on traveling and researching in the remote regions, from village to village, from plateau to plain, and from lakeside to river basin. Rather than simply looking for more effective pesticides, he proposed an integrated approach to control locust plagues, which not only included improved pesticide application, but also focused on regulation of the environment itself. He organized many scientists from

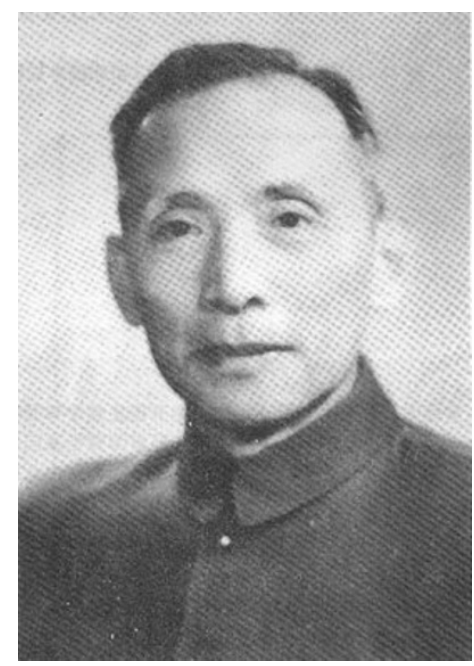

Dr. Shijun Ma (1915-1991)

different disciplines such as insect taxonomy, ecology, physiology, and toxicology and they worked together to study the locust population dynamics, control approaches and environmental changes. With his continuous efforts, the locust plague in China was successfully reduced to a minimal extent by the 1970s.

Before the 1970s, Shijun Ma's research work mainly focused on controlling major insect pests in China, including migratory locusts, armyworms, cotton boll-worms and pine caterpillars. However, he did not limit himself to the traditional approaches commonly seen in pest ecology and control study. As a foreseeing scientist, he started to explore in new disciplines to study insect ecology, and established several research groups covering areas such as mathematical ecology, physical ecology, chemical ecology, geographical 
ecology, and even economic ecology at the Insect Ecology Laboratory in the Institute of Zoology. The scientists he recruited to these groups, including Yanqin Ding, Dianmo Li and Zhongxiong Lan in the mathematical ecology group, Ningsheng Chen and Wuwei Hou in the physical ecology group, Deming Chen and Kunjun Wu in the chemical ecology group, Yonglin Chen and Hongchang Li (plus himself) in the geographical ecology group, and Chengfa Sheng in the economic ecology group, all became the backbones of Chinese insect pest fighting experts later on. His vision was so ahead of his time that he even organized a series of workshops of interdisciplinary research between computer scientists and biologists as early as in the 1960s. All his studies in these disciplines were brand new at that time and greatly broadened the horizons of his peer ecologists in China.

While his insect ecological study moved forward, on the other hand, Shijun Ma began to realize the importance of understanding the whole ecosystem no matter what organism he was working on. Thus, he gradually shifted his research focus from insect ecology to ecosystem ecology, which also was a cutting edge area in China at that time. In the 1970s, he founded the Chinese Society of Ecology, and then established the scientific journal Acta Ecologica Sinica in 1981. To push the studies on the effects of human activities on ecosystem, he made big efforts to promote the Man and the Biosphere (MAB) programme and the International Geosphere-Biosphere Programme (IGBP) in China.

As the development of Chinese industry picked up its pace, the environmental issues also started to emerge. As a scientist with strong social consciousness, Shijun Ma was among the first to see the severeness of the issues, and was probably the first Chinese to seriously worry about global change, environmental pollution, and even nuclear winter. $\mathrm{He}$ also realized that it was urgently needed to combine the power of ecological research and environmental science to fight the environmental issues. In 1975, he promoted the establishment of the Research Center for Eco-Environmental Sciences, Chinese Academy of
Sciences, in which ecological questions linked with pollutions of soil, water, and atmosphere are study emphasis. The Center has now become the leading institute of ecoenvironmental research in China.

Since the 1980s, Shijun Ma started to notice the important role of human being in ecological and environmental issues. He believed that "it is not only the science and technology, but also the consciousness of ecology by the public, which can resolve the environmental crisis in the country." In his late 60s, Shijun Ma put tremendous efforts into raising public awareness of ecological and environmental problems, leaving his footprints all over the country. He also did a great deal of work on influencing the decision-makers with his ecological knowledge, which greatly contributed to the well known state policy "sustainable development."

Because of his academic achievements and social influences, Shijun Ma also served as chairs or board members of many international eco-environmental societies/ committees, including Dr. Gro Harlem Brundtland's World Commission on Environment \& Development. As the only member from China, he contributed a great deal in drafting the famous Brundtland Report: Our Common Future in 1987, and letting the world hear China's standpoint on environment and development as a developing country.

Unfortunately, Shijun Ma died in a tragic car accident on his way back from giving a plenary speech in the Rural Ecoenvironmental Construction Meeting in Hebei Province on May 30, 1991. It is a great loss for the whole Chinese ecology society as well as the environmental science society. With his tireless quest of new areas in his whole life, we wonder where his new exploration would lead us if not for his sudden death.

\section{REFERENCES}

Jiang, G., Li, H., and Polunin, N. (1991). Shijun Ma (1915-1991). Environmental Conservation 18, 365.

$\mathrm{Ma}, \mathrm{S}$. Edited by State Key Laboratory of Urban and Regional Ecology, Chinese Academy of Sciences, et al. (1995). Shijun Ma Collection. Beijing, China Environmental Science Press. (马世骏. 中国科学院生态环境研究中心系统生态开放实验室等编. (1995). 马世骏文集. 北京, 中国环境科学出版社.) 